\title{
Production of reactive oxygen species in Dalbergia nigra seeds under thermal stress ${ }^{1}$
}

\author{
Antônio César Batista Matos²*, Eduardo Euclydes de Lima e Borges², \\ Marcelo Coelho Sekita ${ }^{3}$
}

\begin{abstract}
Seed germination is dependent on abiotic factors, temperature being one of the main ones, whose influence causes seed damage under extreme conditions. The aim of the present study was to investigate the effect of different temperatures during germination of $D$. nigra seeds and their physiological and biochemical implications. We assessed germination percentage and production of superoxide anion $\left(\mathrm{O}_{2}^{-}\right)$and hydrogen peroxide $\left(\mathrm{H}_{2} \mathrm{O}_{2}\right)$ in seeds subjected to temperatures of $5,15,25,35$ and $45^{\circ} \mathrm{C}$ for different periods of time. Hydration is promoted at $45^{\circ} \mathrm{C}$ and inhibited at $5^{\circ} \mathrm{C}$, without germination in either, whereas it is minimal at $15^{\circ} \mathrm{C}$ and at a maximum level at $25^{\circ} \mathrm{C}$. Superoxide production increases at higher temperatures $\left(25\right.$ and $\left.35^{\circ} \mathrm{C}\right)$ after 72 hours of hydration, coinciding with the beginning of radicle protrusion. Production of hydrogen peroxide decreases at all temperatures, except for $5^{\circ} \mathrm{C}$, with values near each other at temperatures of 15,25 , and $35^{\circ} \mathrm{C}$, where there was radicle protrusion.
\end{abstract}

Index terms: forest, physiology, biochemistry, rosewood.

\section{Produção de espécies reativas de oxigênio em sementes de Dalbergia nigra sob estresse térmico}

\begin{abstract}
RESUMO - A germinação de sementes é dependente de fatores abióticos, sendo a temperatura um dos principais, cuja influência, em condições extremas, causa danos às sementes. O presente trabalho teve por objetivo investigar o efeito das diferentes temperaturas durante a germinação de sementes de D. nigra e suas implicações fisiológicas e bioquímicas. Avaliaram-se o porcentual de germinação e a produção de ânion superóxido $\left(\mathrm{O}_{2}^{-}\right)$e peróxido de hidrogênio $\left(\mathrm{H}_{2} \mathrm{O}_{2}\right)$ em sementes submetidas às temperaturas de $5,15,25,35$ e $45{ }^{\circ} \mathrm{C}$ por diferentes tempos. A hidratação é estimulada a $45^{\circ} \mathrm{C}$ e inibida a $5{ }^{\circ} \mathrm{C}$, não havendo germinação em ambas, enquanto é mínima a $15^{\circ} \mathrm{C}$ e máxima a $25^{\circ} \mathrm{C}$. A produção de superóxido aumenta nas temperaturas mais altas $\left(25\right.$ e $\left.35^{\circ} \mathrm{C}\right)$ após 72 horas de hidratação, coincidindo com o início da protrusão radicular. A produção de peróxido de hidrogênio decresce em todas as temperaturas, à exceção da de $5{ }^{\circ} \mathrm{C}$, com valores próximos entre si nas temperaturas de 15 , 25 e $35^{\circ} \mathrm{C}$, onde houve protrusão radicular.
\end{abstract}

Termos para indexação: floresta, fisiologia, bioquímica, jacarandá-da-bahia.

\section{Introduction}

Dalbergia nigra (Vell.) Fr.All. ex Benth, also known as rosewood, is a tree species that occurs in different Brazilian states, especially in areas of the Atlantic Forest Formation. Due to intense exploitation and the lack of reforestation programs, this species has been included as vulnerable on the Red List of the International Union for Conservation of Nature since 1998 (IUCN, 2013), with prohibition of its trade since the 1990s (CITES, 2008), as well as being included on the official list of endangered species of Brazilian flora (IBAMA, 2013). It is propagated through seeds and is indicated for programs of

Submitted on $02 / 25 / 2014$. Accepted for publication on $05 / 26 / 2014$.

${ }^{2}$ Departamento de Engenharia Florestal, UFV, 36570-000 - Viçosa, MG, Brasil. recovery of degraded areas, with high potential for sustainable forest management (Lorenzi, 2002).

Knowledge of seed physiology is fundamental. For each species, specific environmental conditions are necessary to ensure germination, as shown by Araújo Neto et al. (2003) and Rego et al. (2009) for the species Acacia polyphylla and Blepharocalyx salicifolius, respectively. The range of environmental adaptation is related to the cardinal temperatures (minimum, optimum, and maximum) that each species requires for germination, determining the distribution limits of the species (Orozco-Almanza et al., 2003; Borghetti, 2005; Oliveira and Garcia, 2005; Bewley et al., 2013). In relation to 
the seeds of native forest species, the thermal range suitable for germination is frequently from 20 to $30{ }^{\circ} \mathrm{C}$ (Mello and Barbedo, 2007; Brancalion et al., 2010; Pimenta et al., 2010; Dousseau et al., 2013).

Studies in respect to physiological and biochemical aspects during seed germination of tropical species under abiotic stress conditions, especially thermal stress, are highly relevant in the face of environmental adversities found in tropical ecosystems, and also through the lack of information in regard to the mechanisms involved in seed tolerance to determined levels of stress. Plants under abiotic stress conditions, such as drought, salinity, and high and low temperatures, produce reactive oxygen species (ROSs), as observed by Luo et al. (2011), in which low temperature continually increased the formation of superoxide anion and hydrogen peroxide in leaves of Fragaria ananassa Duch., Zoji and Toyonaka cultivars, up to 48 hours, decreasing after that. Airaki et al. (2012) observed an increase in the level of the non-enzymatic antioxidants ascorbate and glutathione and in the activity of the enzyme NADPH dehydrogenase during acclimatization of Capsicum annum L. plants, indicating the action of these substances in the cell antioxidant system. Even in storage under low temperature, there is production of superoxide anion and hydrogen peroxide, as observed by Pukacka and Ratajczak (2005) in Fagus sylvatica seeds stored at temperatures of 4,20 and $30^{\circ} \mathrm{C}$. The loss of viability that occurred in nine weeks under all conditions was related to the increase in the two compounds.

Studies show that the ROSs may not be as harmful to the seed life cycle as previously portrayed, but may have a key role in signaling in response to the different possible stresses during germination (Gomes and Garcia, 2013). The ROSs may be signalers of various biological processes, including responses to biotic and abiotic stresses and programmed cell death (Bailly, 2004; Mittler et al., 2004; Foyer and Noctor, 2005; Fujita et al., 2006). Seeds pass through an infection-sensitive period during germination, and it is believed that the ROSs play an important protective role against attacks from incompatible pathogens (Schopfer et al., 2001; Oracz et al., 2009). Thus, the ROSs play a key role in the seed germination process.

Accordingly, the study of the effect of different temperatures is important, especially those outside of the optimum range for germination, in the germination process and in the production of substances arising from thermal stress, which may result in loss of quality or death of the seeds. Thus, the aim of this study was to assess the germination of Dalbergia nigra seeds under thermal stress conditions in association with the production of reactive oxygen species.

\section{Materials and Methods}

The seeds were collected in September 2012 in the region of Viçosa, MG, Brazil, processed, and placed in cold storage $\left(5^{\circ} \mathrm{C} / 60 \%\right.$ relative humidity- $\left.\mathrm{RH}\right)$.

Percentage of water gain $(\%)$ was calculated in relation to the initial seed weight of each treatment. For that purpose, the seeds were placed in a laboratory oven at $105 \pm 3{ }^{\circ} \mathrm{C}$ for 24 hours (Brasil, 2009), using three replications of 20 seeds. Calculation was made on a wet basis, with the degree of moisture expressed in percentage.

The seeds were weighed on a digital balance with $0.0001 \mathrm{~g}$ precision and subsequently placed for soaking in a Petri dish on two sheets of filter paper moistened with $4.0 \mathrm{~mL}$ of distilled water and kept under constant light at the temperatures of $5,15,25,35$ and $45^{\circ} \mathrm{C}$. The seeds were weighed at two-hour intervals in the first 12 hours and subsequently weighed at 12-hour intervals until they reached $50 \%$ germination or until the tenth day (240 hours) after the beginning of soaking. Before each weighing, the surface of the seeds was dried with absorbent paper, and then they were once more placed in Petri dishes with paper moistened with distilled water. Five replications of 20 seeds were used.

In the germination test, the seeds were immersed in $0.5 \%$ Captan $^{\circledR}$ solution for three minutes and placed in Petri dishes on two sheets of paper moistened with 4.0 $\mathrm{mL}$ of distilled water and kept in a BOD type germinator at the temperatures of $5,15,25,35$ and $45{ }^{\circ} \mathrm{C}$ under constant light for 240 hours. Daily assessments were made, with protrusion of the primary root as the criterion of germination. Each treatment (temperature) consisted of five replications of 20 seeds.

The effect of temperature on production of reactive oxygen species (ROSs) was assessed by comparing production levels during germination. Seeds began primary root protrusion at 132 hours of soaking at the temperature of $25{ }^{\circ} \mathrm{C}$, used as the standard. That way, analyses were made of the embryonic axes of seeds that were soaked for 0 hours (dry seeds) and 24, 72 and 120 hours, which correspond to the end of phase I, and the middle and end of phase II, respectively. The same sample taking times were used for the temperatures of 5,15 and $35^{\circ} \mathrm{C}$. For the temperature of $45^{\circ} \mathrm{C}$, samples were taken at 8 and 24 hours since preliminary tests had indicated death of the seeds after 24 hours at that temperature. The seeds were placed under the same conditions of the germination test.

In quantification of superoxide anion, samples of 20 embryonic axes were weighed on a balance with $0.0001 \mathrm{~g}$ 
precision and cut in half in the transversal direction in two segments and incubated in $2.0 \mathrm{~mL}$ of reaction medium consisting of disodium salt of $100 \mu \mathrm{M}$ Ethylenediamine tetraacetic acid ( $\mathrm{Na}_{2}$ EDTA), $20 \mu \mathrm{M} \quad \beta$-Nicotinamide adenine dinucleotide reduced (NADH), and $20 \mathrm{mM}$ sodium phosphate buffer, pH 7.8 (Mohammadi and Karr, 2001) in hermetically sealed tubes. The reaction was started by the introduction of $100 \mu \mathrm{L}$ of $25.2 \mathrm{mM}$ epinephrine in $0.1 \mathrm{~N} \mathrm{HCl}$, using a chromatography syringe. Samples were incubated at $28{ }^{\circ} \mathrm{C}$, remaining under shaking for 5 minutes. After that, the segments were removed and, as of the seventh minute, reading of absorbance at $480 \mathrm{~nm}$ was begun in a Thermo Scientific EVOLUTION 60S spectrophotometer, which was carried out for five minutes. The blank was performed under the same conditions, but without plant tissue. Production of superoxide anion was assessed by determination of the amount of accumulated adrenochrome (Misra and Fridovich, 1971), using the molar absorption coefficient of $4.0 \times 10^{3} \mathrm{M}^{-1}$ (Boveris, 1984).

For quantification of hydrogen peroxide, samples of 20 embryonic axes were weighed on a 0.0001 g-precision balance, ground in liquid nitrogen, and then homogenized in $2.0 \mathrm{~mL}$ of $50 \mathrm{mM}$ potassium phosphate buffer, $\mathrm{pH} 6.5$, containing $1 \mathrm{mM}$ hydroxylamine, followed by centrifugation at $10,000 \mathrm{~g}$ for 15 minutes at $4{ }^{\circ} \mathrm{C}$, and the supernatant was collected (Kuo and Kao, 2003).

Aliquots of $100 \mu \mathrm{L}$ of the supernatant were added to the reaction medium consisting of $250 \mu \mathrm{M}$ ferrous ammonium sulfate, $25 \mathrm{mM}$ sulfuric acid, $250 \mu \mathrm{M}$ xylenol orange, and $100 \mathrm{mM}$ sorbitol in a final volume of $2 \mathrm{~mL}$ (Gay and Gebicki, 2000), homogenized, and kept in the dark for 30 minutes. Absorbance was determined in a Thermo Scientific EVOLUTION 60S spectrophotometer at $560 \mathrm{~nm}$, and quantification of $\mathrm{H}_{2} \mathrm{O}_{2}$ was made based on a calibration curve, using peroxide concentrations as a standard. Blanks for the reagents and plant extracts were prepared in a parallel manner and taken from the sample.

The data were subjected to analysis of variance (ANOVA). For germination, a single-factor completely randomized design (5 temperatures) was used, and subjected to regression analysis.

For ROS production data, a completely randomized design in a $4 \times 4$ factorial arrangement $\left(5,15,25\right.$ and $35^{\circ} \mathrm{C} \mathrm{x} 0,24,72$, and 120 hours) was used, plus 4 additional treatments $\left(45^{\circ} \mathrm{C}\right.$ $\mathrm{x} 0,8,24$ and 48 hours). The statistical model $\mathrm{Y}_{\mathrm{ij}}=\mathrm{m}+\mathrm{t}_{\mathrm{i}}+\mathrm{e}_{\mathrm{ij}}$ was used for the 20 treatments, with one factorial with 15 degrees of freedom $\left(5,15,25\right.$ and $35^{\circ} \mathrm{C} \times 0,24,72$ and 120 hours), the additional treatments with 3 degrees of freedom (45 ${ }^{\circ} \mathrm{C} \times 0,8,24$ and 48 hours), and a contrast between factorial $x$ additional with 1 degree of freedom, exhibiting the ANOVA tables (Tables 1 and 2). The regression models were chosen based on biological logic, at the significance of the regression coefficients, using the $t$ test at $5 \%$ probability and in the coefficient of determination. The software Statistica 8 (STATSOFT Inc., 2009) was used.

Table 1. Summary of analysis of variance (ANOVA) for the data on production of superoxide anion $\left(\mathrm{O}_{2}^{-}\right)$in embryonic axes of Dalbergia nigra seeds under different temperatures.

\begin{tabular}{ccrrrr}
\hline Sources of Variation & DF & \multicolumn{1}{c}{ SS } & \multicolumn{1}{c}{ MS } & F & p-value \\
\hline Treatments & 19 & 12846.73 & 676.14 & 329.46 & 0.0000 \\
Factorial & 15 & 10147.25 & 676.48 & 329.63 & 0.0000 \\
Temperature (T) & 3 & 33.63 & 11.21 & 5.46 & 0.0030 \\
Period (P) & 3 & 10028.39 & 3342.80 & 1628.83 & 0.0000 \\
T x P & 9 & 85.24 & 9.47 & 4.61 & 0.0003 \\
Additional & 3 & 2691.70 & 897.23 & 437.19 & 0.0000 \\
Factorial vs Additional & 1 & 7.78 & 7.78 & 3.79 & 0.0585 \\
\hline Error & 40 & 82.0909 & 2.0523 & &
\end{tabular}

$\mathrm{DF}=$ degrees of freedom; $\mathrm{SS}=$ sum of squares; $\mathrm{MS}=$ mean square; $\mathrm{F}=$ value of the $\mathrm{F}$ test; $\mathrm{p}$-value=probability of significance. 
Table 2. Summary of analysis of variance (ANOVA) for the data on production of hydrogen peroxide $\left(\mathrm{H}_{2} \mathrm{O}_{2}\right)$ in embryonic axes of Dalbergia nigra seeds under different temperatures.

\begin{tabular}{ccrrrr}
\hline Sources of Variation & DF & \multicolumn{1}{c}{ SS } & \multicolumn{1}{c}{ MS } & \multicolumn{1}{c}{ F } & p-value \\
\hline Treatments & 19 & 4730.26 & 248.96 & 73.92 & 0.0000 \\
Factorial & 15 & 3600.22 & 240.01 & 71.27 & 0.0000 \\
Temperature (T) & 3 & 44.98 & 14.99 & 4.45 & 0.0086 \\
Period (P) & 3 & 3453.93 & 1151.31 & 341.86 & 0.0000 \\
T x P & 9 & 101.31 & 11.26 & 3.34 & 0.0039 \\
Additional & 3 & 1125.19 & 375.06 & 111.37 & 0.0000 \\
Factorial vs Additional & 1 & 4.85 & 4.85 & 1.44 & 0.2371 \\
\hline Error & 40 & 134.71 & 3.37 & & \\
\hline Total & 59 & 4864.97 & & &
\end{tabular}

$\mathrm{DF}=$ degrees of freedom; $\mathrm{SS}=$ sum of squares; $\mathrm{MS}=$ mean square; $\mathrm{F}=$ value of the $\mathrm{F}$ test; $\mathrm{p}$-value=probability of significance.

\section{Results and Discussion}

The Dalbergia nigra seeds were dispersed with moisture content of $8.86 \%$, which was similar to the values of moisture content found by Ataíde et al. (2013) for two lots of seeds of the same species collected in 2010 and 2011 (7.92 and $8.98 \%$, respectively) in the region of Viçosa, MG, Brazil. According to the imbibition curves, temperature stimulated the rate of water uptake; weight gain of the seeds increased through increase in temperature. At the temperature of $5{ }^{\circ} \mathrm{C}$, the lowest rate of water uptake was observed, requiring 72 hours to reach phase II. At the temperature of $15{ }^{\circ} \mathrm{C}, 36$ hours were necessary to characterize phase II, while at the temperatures of 35 and $45{ }^{\circ} \mathrm{C}, 24$ hours were necessary. However, deterioration of the seeds began over the period at the temperature of $45{ }^{\circ} \mathrm{C}$. The seeds remained at phase II at the temperatures of 5 and $45^{\circ} \mathrm{C}$. For the temperature of $25^{\circ} \mathrm{C}$, the three phase imbibition pattern was observed, reaching phase III in 132 hours (Figure 1).

Significant effects of temperatures on germination of D. nigra seeds were observed (Figure 2). At $25{ }^{\circ} \mathrm{C}$, the seeds reached the maximum estimated percentage of germination for the 12 days $(94 \%)$. For the temperatures of 5 and $45^{\circ} \mathrm{C}$, there was no radicle protrusion during the period of observation. Seed imbibition at low temperatures has a harmful effect because it results in irreparable damage to the membranes and leaching of solutes (Castro et al., 2004). High temperatures may allow seed imbibition; however, they do not ensure embryo expansion and seedling establishment (Bradbeer, 1988). In regard to temperatures of 15 and $35{ }^{\circ} \mathrm{C}$, the D. nigra seeds reached the maximum estimated percentages of germination at 12 days, with $5 \%$ and $39 \%$ of germination, respectively.

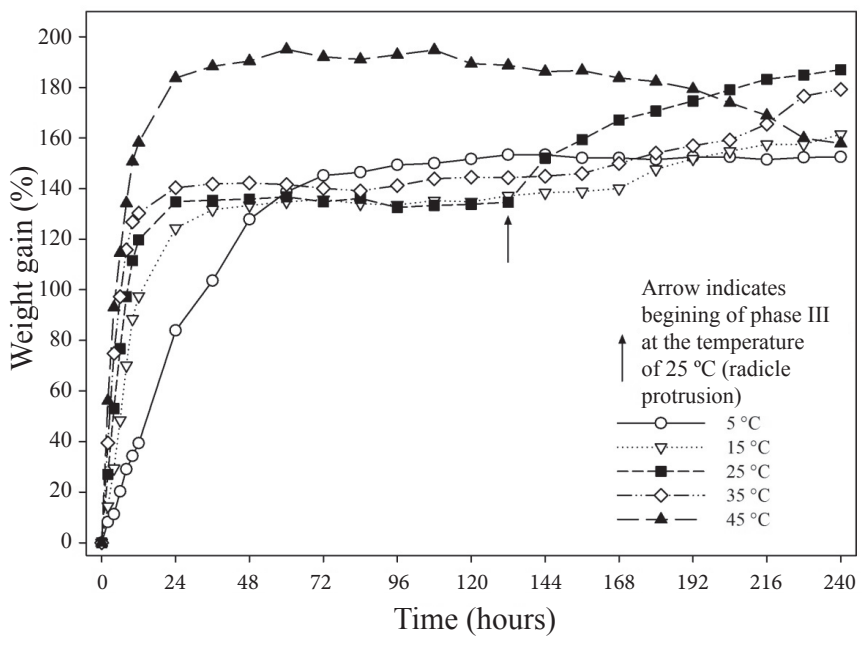

Figure 1. Imbibition curves of Dalbergia nigra seeds under different temperatures.

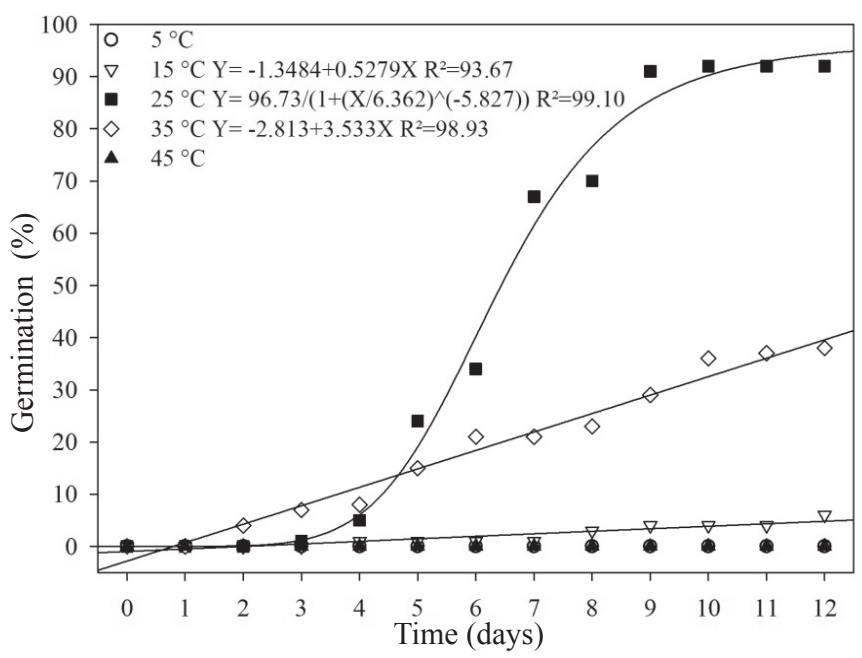

Figure 2. Regression equations for germination of Dalbergia nigra seeds under different temperatures. 
The balance between ROS production and the capacity of the defense system in their removal indicates the plant response to stress and reflects adaptation and/or tolerance to the different types of environmental conditions (Mittler, 2002; Apel and Hirt, 2004). The radical $\mathrm{O}_{2}{ }^{-}$may lead to cell death when there is no specific antioxidant defense system to remove it (Gill and Tuteja, 2010). The conversion of $\mathrm{O}_{2}{ }^{-}$to $\mathrm{H}_{2} \mathrm{O}_{2}$ is the natural route for removal of both substances due to the fact that the latter is less toxic than the former, as well as the possibility of being taken from the production location. Moreover, according to Gill and Tuteja (2010), the accumulation of $\mathrm{H}_{2} \mathrm{O}_{2}$ in the cells may cause damage to cell metabolism since this compound has the ability of oxidizing the thiol groups (-SH) of enzymes, deactivating them.

The production of $\mathrm{O}_{2}^{-}\left(34.01 \mathrm{nmol} \cdot \mathrm{min}^{-1} \cdot \mathrm{g}^{-1} \mathrm{FM}\right)$ and $\mathrm{H}_{2} \mathrm{O}_{2}$ (34.20 $\left.\mu \mathrm{mol} . \mathrm{g}^{-1} \mathrm{FM}\right)$ in embryonic axes of dry $D$. nigra seeds was observed (Figures 3 and 4). In this case, the presence of ROSs may arise from non-enzymatic reactions, such as lipid peroxidation and the Amadori and Maillard reactions since the enzyme activity of the antioxidant system is probably reduced in this condition (Murthy et al., 2003). Pukacka and Ratajczak (2005) also found hydrogen peroxide production in dry Fagus sylvatica seeds. With the beginning of imbibition, there was a reduction in the concentration of $\mathrm{O}_{2}{ }^{-}$and $\mathrm{H}_{2} \mathrm{O}_{2}$ for all the temperatures assessed.

For the temperature of $5{ }^{\circ} \mathrm{C}$, reduction in $\mathrm{O}_{2}^{-}$production soon after imbibition was seen, when compared with the value of the dry seed, reaching minimum values up to 120 hours (Figure 3). Luo et al. (2011) observed a continual increase in the formation of superoxide anion in strawberry leaves under low temperature up to 48 hours, decreasing after that. During acclimatization of Capsicum annum seedlings to low temperature, Airaki et al. (2012) observed an increase in the level of the non-enzymatic antioxidants ascorbate and glutathione and in the activity of the NADPH dehydrogenase.

In relation to production of hydrogen peroxide, at the temperature of $5^{\circ} \mathrm{C}$, minimum production of this free radical was seen up to 70 hours of imbibition $\left(9.6 \mu \mathrm{mol} . \mathrm{g}^{-1} \mathrm{FM}\right)$ and subsequent increase in this production up to 120 hours $(20.5$ $\left.\mu \mathrm{mol} . \mathrm{g}^{-1} \mathrm{FM}\right)$ (Figure 4). The high moisture content of the seeds associated with the increase in the hydrogen peroxide content compromised the germination process. Okane et al. (1996) observed that $\mathrm{H}_{2} \mathrm{O}_{2}$ production in calluses of Arabidopsis thaliana plants was greater at $4{ }^{\circ} \mathrm{C}$ than at $23{ }^{\circ} \mathrm{C}$. Similar results were found by Sun et al. (2010), who observed accumulation of $\mathrm{H}_{2} \mathrm{O}_{2}$ in leaf tissue under low temperature conditions in Nicotiana tabacum seedlings. According to Torres and Dangl (2005), there was expression of various genes in different species when the plants were subjected to low temperature. Thus, there is a clear presence of ROSs as a reaction to temperature stress for $D$. nigra seeds.

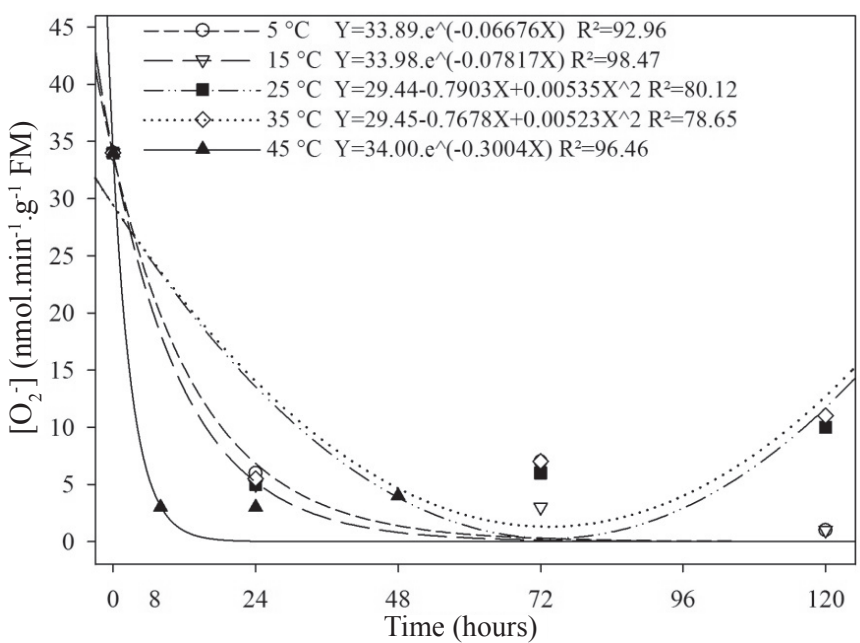

Figure 3. Superoxide anion $\left(\mathrm{O}_{2}^{-}\right)$production in embryonic axes of Dalbergia nigra seeds during germination under different temperatures.

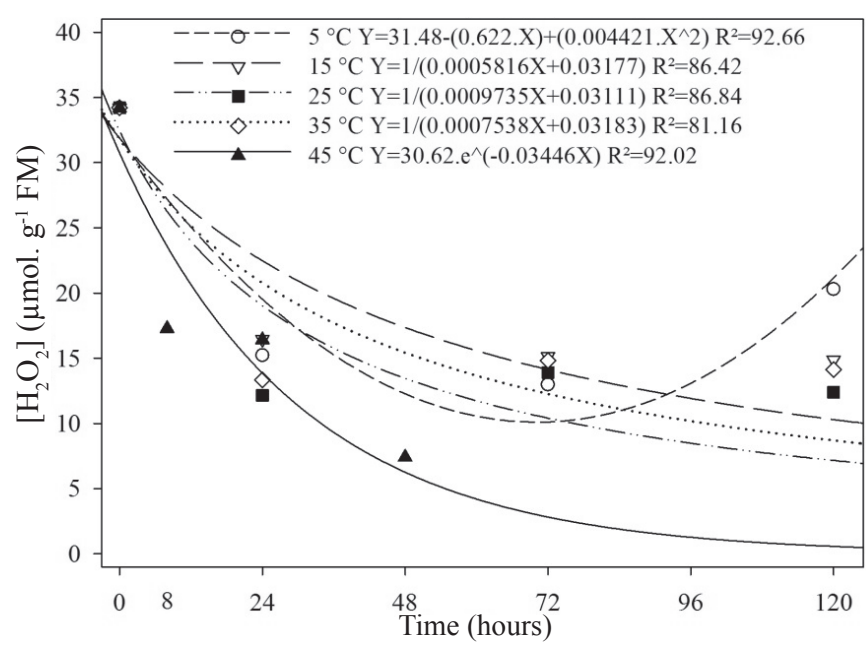

Figure 4. Hydrogen peroxide $\left(\mathrm{H}_{2} \mathrm{O}_{2}\right)$ production in embryonic axes of Dalbergia nigra seeds during germination under different temperatures.

There was continual reduction in $\mathrm{O}_{2}^{-}$production at the temperature of $15^{\circ} \mathrm{C}$ up to 120 hours (Figure 3), showing effective action of the enzymes responsible for elimination of the ROSs. The concentration of hydrogen peroxide also decreased up to 120 hours (Figure 4). As it was not under optimum germination conditions $(5 \%$ radicle protrusion in 120 hours), the production of hydrogen peroxide was still a reaction to thermal stress. It may be seen that the concentration of $\mathrm{H}_{2} \mathrm{O}_{2}$ at this temperature $\left(9.84 \mu \mathrm{mol} . \mathrm{g}^{-1} \mathrm{FM}\right)$ is greater than 
at $25{ }^{\circ} \mathrm{C}\left(6.75 \mu \mathrm{mol} . \mathrm{g}^{-1} \mathrm{FM}\right)$ and at $35^{\circ} \mathrm{C}\left(8.17 \mu \mathrm{mol} . \mathrm{g}^{-1} \mathrm{FM}\right)$ up to 120 hours of imbibition. Germination at this temperature indicates that the respiratory system in the mitochondria is occurring, with consequent production of superoxide anion, effectively dismuted by the SOD enzyme.

Minimum production of superoxide anion at the temperature of $25{ }^{\circ} \mathrm{C}$ occurred at 74 hours of imbibition $\left(0.27 \mathrm{nmol} . \mathrm{min}^{-1} \cdot \mathrm{g}^{-1} \mathrm{FM}\right)$, rising afterwards up to 120 hours (11.70 nmol. $\mathrm{min}^{-1} \cdot \mathrm{g}^{-1} \mathrm{FM}$ ) (Figure 3), when the seeds reached $19 \%$ radicle protrusion. Hydrogen peroxide, after a decrease during imbibition in relation to the control, remained relatively high up to 120 hours (Figure 4). The production of ROSs acts against pathogens during radicle protrusion, and also acts as a component of cell growth when it induces the depolymerization of components of the cell well, permitting the cellular expansion (Bailly, 2004; Muller et al., 2009).

At the temperature of $35^{\circ} \mathrm{C}$, minimum production of $\mathrm{O}_{2}^{-}$ was observed at 73 hours of imbibition (1.27 nmol. $\mathrm{min}^{-1} \cdot \mathrm{g}^{-1}$ FM) (Figure 3), increasing continually up to 120 hours (12.62 nmol. $\left.\mathrm{min}^{-1} \cdot \mathrm{g}^{-1} \mathrm{FM}\right)$, when $15 \%$ protrusion of the primary root was reached. There were small variations in the values of hydrogen peroxide during the period, which were lower than those at the temperature of $15^{\circ} \mathrm{C}$, but greater than those at $25^{\circ} \mathrm{C}$ (Figure 4). As the percentage of germination was only $40 \%$ after 240 hours $(94 \%$ germination at the temperature of $25^{\circ} \mathrm{C}$ ) and the production of superoxide anion was greater among the temperatures assessed, it is clear that at $35^{\circ} \mathrm{C}$ there is metabolic damage to the seeds. As the ROSs are produced in the mitochondria, in the glyoxysome, and in the plasmatic membrane, the system for control of the levels of superoxide anion and hydrogen peroxide could be in any one of them. As the increase in temperature corresponds to the increase in respiration, the production of ROSs on a greater scale in the mitochondria would have the consequence of change in their membranes and reduction in production of ATP and death of the seeds. The presence of $\mathrm{H}_{2} \mathrm{O}_{2}$ could be in the stress signaling system, when at $5{ }^{\circ} \mathrm{C}$ or at $35^{\circ} \mathrm{C}$, or in growth and protection at the temperature of $25^{\circ} \mathrm{C}$. This is more certain in the last case since there was no interference in germination.

At the temperature of $45{ }^{\circ} \mathrm{C}$, a $91 \%$ reduction was observed in $\mathrm{O}_{2}$ - production up to 8 hours of imbibition when compared to the value of the dry seeds, until reaching values near zero at 120 hours of imbibition (Figure 3). The $\mathrm{H}_{2} \mathrm{O}_{2}$ concentration reduced $99 \%$ in 8 hours of imbibition when compared with the value of the dry seeds, until reaching 0.49 $\mu$ mol.g ${ }^{-1}$ FM after 120 hours of imbibition (Figure 4). Duan et al. (2009) established $40^{\circ} \mathrm{C}$ as the optimum temperature for activity of the enzyme NADPH oxidase in rice seeds. Thus, at the temperature of $45^{\circ} \mathrm{C}$, there may still be activity of this enzyme, which may have an effect on the production of superoxide anion and a consequent harmful effect on seed viability. Maintenance of the $\mathrm{H}_{2} \mathrm{O}_{2}$ may be by the action of NADPH oxidase since, according to Sagi and Fluhr (2006), the production of hydrogen peroxide between the cell membrane and wall could return in the form of hydroperoxide, formed by the effect of the 5.0 extracellular $\mathrm{pH}$, and, that way, would enable the action of the SOD in catalyzation of the formation of hydrogen peroxide. Thus, it is possible to suppose action of the enzyme already in the initial periods of germination. Kranner et al. (2010) observed an increase in $\mathrm{O}_{2}^{-}$production with an increase in temperature during experiments carried out with Pisum sativum seeds. Wang et al. (2012) observed an increase in production of ROSs, especially hydrogen peroxide and an increase in lipid peroxidation in soybean seeds under high temperature and moisture conditions. According to Bhattacharjee (2008), high temperature induced a significant increase in the superoxide anion and hydrogen peroxide content in Amaranthus livindus seeds and seedlings when compared to the control group. The involvement of other mechanisms in the effects of temperature on the reduction of viability or death of seeds may not be dismissed. According to Larkindale et al. (2005), heat resistance or the acquisition of thermotolerance is a complex multigenic process.

\section{Conclusions}

Hydration is stimulated at $45^{\circ} \mathrm{C}$ and inhibited at $5{ }^{\circ} \mathrm{C}$, without germination in either, whereas it is minimal at $15^{\circ} \mathrm{C}$ and at a maximum level at $25^{\circ} \mathrm{C}$.

Superoxide production increases at higher temperatures $\left(25\right.$ and $35^{\circ} \mathrm{C}$ ) after 72 hours of hydration, coinciding with the beginning of radicle protrusion.

Hydrogen peroxide production decreases at all temperatures, except for $5{ }^{\circ} \mathrm{C}$, with values near each other at the temperatures of 15,25 and $35^{\circ} \mathrm{C}$, where there was radicle protrusion.

\section{References}

AIRAKI, M.; LETERRIER, M.; MATEOS, R.M.; VALDERRAMA, R.; CHAKI, M.; BARROSO, J.B.; DEL RIO, L.A.; PALMA, J.M.; CORPAS, F.J. Metabolism of reactive oxygen species and reactive nitrogen species in pepper (Capsicum annum L.) plants under low temperature stress. Plant Cell Environment, v.35, n.2, p.281-295, 2012. http://onlinelibrary.wiley.com/ doi/10.1111/j.1365-3040.2011.02310.x/full

APEL, K.; HIRT, H. Reactive oxygen species: metabolism, oxidative stress and signal transduction. Annual Review of Plant Biology, v.55, p.373-399, 2004. http://www.annualreviews.org/doi/abs/10.1146/ annurev.arplant.55.031903.141701?url_ver=Z39.88-2003\&rfr_dat $=\mathrm{cr}$ pub\%3Dpubmed\&rfr_id=ori\%3Arid\%3Acrossref.org\&journalCode=arplant 
ARAÚJO NETO, J.C.; AGUIAR, I.B.; FERREIRA, V.M. Efeito da temperatura e da luz na germinação de sementes de Acacia polyphylla DC. Revista Brasileira de Botânica, v.26, n.2, p.249-256, 2003. http://www. scielo.br/pdf/rbb/v26n2/a13v26n2.pdf

ATAÍDE, G.M.; BORGES, E.E.L.; GONCALVES, J.F.C.; GUIMARÃES, V.M.; FLORES, A. V.; BICALHO, E.M. Alterations in seed reserves of Dalbergia nigra ((Vell.) Fr All. ex Benth.) during hydration. Journal of Seed Science, v.35, n.1, p.56-63, 2013. http://www.scielo.br/pdf/jss/v35n1/08.pdf

BAILLY, C. Active oxygen species and antioxidants in seed biology. Seed ScienceandResearch,v.14,p.93-107,2004.http://journals.cambridge.org/action/ displayAbstract;jsessionid=B80FC3066251AA4A792970AD5C0FA8C9. journals? fromPage $=$ online\&aid $=709508$

BEWLEY, J.D.; BRADFORD, K.J.; HILHORST, H.W.M.; NONOGAKI, H. Seeds: physiology of development, germination and dormancy. New York: Springer, 2013, 392p

BHATTACHARJEE, S. Calcium-dependent signaling pathway in the heat-induced oxidative injury in Amaranthus lividus. Biologia Plantarum, v.52, p.137-140, 2008. http://link.springer.com/ article $/ 10.1007 \% 2$ Fs $10535-008-0028-1$

BORGHETTI, F. Temperaturas extremas e a germinação de sementes. In: NOGUEIRA, R.J.M.C.; ARAÚJO, E.L.; WILLADINO, L.G.; CAVALCANTE, U.M.T. (eds.). Estresses ambientais: Danos e benefícios em plantas. Recife: UFPE, 2005. p.207-218.

BOVERIS, A. Determination of superoxide radicals and hydrogen peroxide in mithocondria. Methods in enzymology, v.105, p.429-435, 1984.

BRADBEER, J.W. Seed dormancy and germination. New York: Chapman and Hall, 1988. 146p.

BRANCALION, P.H.S.; NOVEMBRE, A.D.L.C.; RODRIGUES, R.R. Temperatura ótima de germinação de sementes de espécies arbóreas brasileiras. Revista Brasileira de Sementes, v.32, n.4, p.15-21, 2010. http:// www.scielo.br/pdf/rbs/v32n4/02.pdf

BRASIL. Ministério da Agricultura, Pecuária e Abastecimento. Regras para análise de sementes. Ministério da Agricultura, Pecuária e Abastecimento. Secretaria de Defesa Agropecuária. Brasília: MAPA/ACS, 2009. 395p. http:// www.agricultura.gov.br/arq_editor/file/2946_regras_analise_sementes.pdf

CASTRO, R.D.; BRADFORD, K.J.; HILHORST, H.W.M. Embebição e reativação do metabolismo. In: FERREIRA, A.G.; BORGHETTI, F. (orgs). Germinação: do básico ao aplicado, Porto Alegre: Artmed, 2004. p.149-162.

CITES. Convention on International Trade in Endangered Species of Wild Fauna and Flora. CITES: Appendix I, II and III to the Convention on International Trade in Endangered Species of Wild Fauna and Flora. US Fish and Wildlife Service: Washington. 2008. http://www.cites.org/sites/default/ files/eng/app/2013/E-Appendices-2013-06-12.pdf Accessed on: 10 Feb. 2013.

DOUSSEAU, S.; ALVARENGA, A.A.; ARANTES, L.O.; CHAVES, I.S.; AVELINO, E.V. Technology of Qualea grandiflora Mart. (Vochysiaceae) seeds. Cerne, v.19, n.1, p.93-101, 2013. http://www.scielo.br/pdf/cerne/v19n1/12.pdf

DUAN, Z.Q.; BAI, L.; ZHAO, Z.G.; ZHANG, G.P.; CHENG, F.M.; JIANG, L.X.; CHEN, K.M. Drought-stimulated activity of plasma membrane nicotinamide adenine dinucleotide phosphate oxidase and its catalytic properties in rice. Journal Integrative Plant Biology, v.51, n.12, p.1104-1115, 2009. http:// onlinelibrary.wiley.com/doi/10.1111/j.1744-7909.2009.00879.x/full
FOYER, C.H.; NOCTOR, G. Redox homeostasis and antioxidant signaling: a metabolic interface between stress perception and physiological responses. Plant Cell, v.17, p.1866-1875, 2005. http://www.plantcell.org/ content/17/7/1866.full.pdf+html

FUJITA, M; FUJITA, Y; NOUTOSHI, Y; TAKAHASHI, F; NARUSAKA, Y; YAMAGUCHI-SHINOZAKI, K; SHINOZAKI, K. Crosstalk between abiotic and biotic stress responses: a current view from the points of convergence in the stress signaling networks. Currents Opinion Plant Biology, v.9, p.436-442, 2006. http://www.sciencedirect.com/science/article/ $\mathrm{pii} / \mathrm{S} 1369526606000884$

GAY, C.; GEBICKI, J.M. A critical evaluation of the effect of sorbitol on the ferric-xylenol orange hydroperoxide assay. Analytical Biochemistry, v.284, p.217-220, 2000. http://www.sciencedirect.com/science/article/pii/ S0003269700946967

GILL, S.S.; TUTEJA, N. Reactive oxygen species and antioxidant machinery in abiotic stress tolerance in crop plants. Plant Physiology and Biochemistry, v.48, p.909-930. 2010. http://www.sciencedirect.com/science/article/pii/ S0981942810001798

GOMES, M.G.; GARCIA, Q.S. Reactive oxygen species and seed germination. Biologia, v.68, p.351-357, 2013. http://link.springer.com/ article/10.2478\%2Fs11756-013-0161-y

IBAMA. Instituto Brasileiro do Meio Ambiente e dos Recursos Naturai Renováveis. Lista Oficial de Flora ameaçada de extinção. http://www.ibama. gov.br/documentos/lista-de-especies-ameacadas-de-extincao Accessed on: 10 Feb. 2013.

IUCN. International Union for Conservation of Nature and Natural Resources The IUCN Red List of Threatened Species. 2013. http://www.iucnredlist.org/ Accessed on: 10 Feb. 2013.

KRANNER, I.; ROACH, T; BECKETT, R.P.; WHITAKER, C; FARIDA, V.M. Extra cellular production of reactive oxygen species during seed germination and early seedling growth in Pisum sativum. Journal of Plant Physiology, v.167, p.805-811. 2010. http://www.sciencedirect.com/science/ article/pii/S0176161710000945\#

KUO, M.C.; KAO, C.H. Aluminum effects on lipid peroxidation and antioxidative enzyme activities in rice leaves. Biologia Plantarum, v.46, p.149-152, 2003. http://download.springer.com/ static/pdf/864/art\%253A $10.1023 \% 252 \mathrm{FA} \% 253 \mathrm{~A} 1022356322373$. pdf?auth66=1392913488_982040178578e21d9dca009621c469ad\&ext=.pdf

LARKINDALE, J.; HALL, J.D.; KNIGHT, M.R.; VIERLING, E. Heat stress phenotypes of Arabidopsis mutants implicate multiple signaling pathways in the acquisition of thermotolerance. Plant Physiology, v.138, p.882-897, 2005. http://www.plantphysiol.org/content/138/2/882.full.pdf+html

LORENZI, M. Árvores brasileiras: manual de identificação e cultivo de plantas arbóreas nativas do Brasil. Nova Odessa: Plantarum, 2002. 352p.

LUO, Y.; TANG, H.; ZHANG, Y. Production of reactive oxygen species and antioxidant metabolism about strawberry leaves to low temperatures. Journal Agricultural Science, v.3, n.2, p.89-96, 2011. http://www.ccsenet.org/journal/ index.php/jas/article/view/6660/7805

MELLO, J.I.O.; BARBEDO, C.J. Temperatura, luz e substrato para a germinação de sementes de pau-brasil (Caesalpinia echinata Lam. Leguminosae-Caesalpiniodeae). Revista Árvore, v.31, p.645-655, 2007. http://www.scielo.br/pdf/rarv/v31n4/09.pdf 
MISRA, H.P.; FRIDOVICH, I. The generation of superoxide radical during the autoxidation of ferredoxins. The Journal of Biological Chemistry, v.246, n.22, p.6886-6890, 1971. http://www.jbc.org/content/246/22/6886.full.pdf

MITTLER, R. Oxidative stress, antioxidants and stress tolerance. Trends Plant Science, v.7, p.405-410, 2002. http://www.sciencedirect.com/science/ article/pii/S1360138502023129

MITTLER, R; VANDERAUWERA, S; GOLLERY, M; VAN BREUSEGEM, F. Reactive oxygen gene network of plants. Trends Plant Science, v.9, p.490-498, 2004. http://www.sciencedirect.com/science/article/pii/S1360138504002043

MOHAMMADI, M.; KARR, A.L. Superoxide anion generation in effective and ineffective soybean root nodules. Journal of Plant Physiology, v.158, p.1023-1029, 2001. http://ac.els-cdn.com/S0176161704701261/1-s2.0S0176161704701261-main.pdf?_tid=b7b81844-98ba-11e3-bfc4-00000aacb $35 f \& a c d n a t=1392741526 \quad 26 \mathrm{~d} 7 \mathrm{c} 65 \mathrm{a} 6 \mathrm{e} 5015491654507 \mathrm{bf} 2573 \mathrm{~b} 24$

MULLER, K.; LINKIES, A.; VREEBURG RAM, F.S.C.; KRIEGERLISZKAY, A.; LEUBNER-METZGER, G. In vivo cell wall loosening by hydroxyl radicals during cress seed germination and elongation growth. Plant Physiology, v.150, p.1855-1865, 2009. http://www.plantphysiol.org/ content/150/4/1855.full.pdf $+\mathrm{htm}$

MURTHY, U.M.N.; KUMAR, P.P; SUN, W.Q. Mechanisms of seed ageing under different storage conditions for Vigna radiate (L.) Wilczek: lipid peroxidation, sugar hydrolysis, Maillard reactions and their relationship to glass state transition. Journal Experimental of Botany, v.54, p.1057-1067, 2003. http://jxb.oxfordjournals.org/content/54/384/1057.full.pdf + html

OKANE, D.; GILL, V.; BOYD, P.; BURDON, R. Chilling, oxidative stress and antioxidant responses in Arabidopsis thaliana callus. Planta, v.198, p.371-377, 1996. http://link.springer.com/article/10.1007\%2FBF00620053

OLIVEIRA, P.G.; GARCIA, Q.S. Efeitos da luz e da temperatura na germinação de sementes de Syngonanthus elegantulus, S. elegans e $S$. venustus (Eriocaulaceae). Acta Botanica Brasilica, v.19, n.3, p.627-633, 2005. http://www.scielo.br/pdf/abb/v19n3/27380.pdf

ORACZ, K.; EL-MAAROUF-BOUTEAU, H.; KRANNER, I.; BOGATEK, R.; CORBINEAU, F.; BAILLY, C. The mechanisms involved in seed dormancy alleviation by hydrogen cyanide unravel the role of reactive oxygen species as key factors of cellular signaling during germination. Plant Physiology, v.150, p.494-505, 2009. http://www.plantphysiol.org/content/150/1/494

OROZCO-ALMANZA， M.S.; LEON-GARCIA， L.P.; GRETHER, R.; GARCIA-MOYA, E. Germination of four species of the genus Mimosa (Leguminosae) in a semi-arid zone of Central Mexico. Journal of Arid Environments, v.55, p.75-92, 2003. http://www.sciencedirect.com/science/ article/pii/S0140196302002653
PIMENTA, R.S.; LUZ, P.B.; PIVETTA, K.F.L.; CASTRO, A.; PIZETTA, P.U.C. Efeito da maturação e temperatura na germinação de sementes de Phoenix canariensis hort. ex Chabaud-ARECACEAE. Revista Árvore, v.34, p.31-38, 2010. http://www.scielo.br/pdf/rarv/v34n1/v34n1a04

PUKACKA, S.; RATAJCZAK, E. Production and scavenging of reactive oxygen species in Fagus sylvatica seeds during storage at varied temperature and humidity. Journal Plant Physiology, v.162, n.8, p.873-885, 2005. http:// www.sciencedirect.com/science/article/pii/S0176161705000337

REGO, S.S.; NOGUEIRA, A.C.; KUNIYOSHI, Y.S.; SANTOS, Á.F Germinação de sementes de Blepharocalyx salicifolius (H.B.K.) Berg. em diferentes substratos e condições de temperaturas, luz e umidade. Revista Brasileira de Sementes, v.31, n.2, p.212-220, 2009. http://www.scielo.br/pdf/ $\mathrm{rbs} / \mathrm{v} 31 \mathrm{n} 2 / \mathrm{v} 31 \mathrm{n} 2 \mathrm{a} 25 . \mathrm{pdf}$

SAGI, M.; FLUHR, R. Production of reactive oxygen species by plant NADPH oxidases. Plant Physiology, v.141, p.336-340, 2006. http://www. plantphysiol.org/content/141/2/336.full.pdf + html

SCHOPFER, P.; PLACHY, C.; FRAHRY, G. Release of reactive oxygen intermediates (superoxide radicals, hydrogen peroxide, and hydroxyl radicals) and peroxidase in germinating radish seeds controlled by light, gibberellin, and abscisic acid. Plant Physiology, v. 125, p.1591-1602, 2001. http://www.plantphysiol.org/content/125/4/1591.full.pdf+htm

STATSOFT, Inc. STATISTICA. Data analysis software system, version 8 2009. www.statsoft.com.

SUN, W.H.; DUAN, M.; LI, F.; SHU, D.F.; YANG, S.; WENG, Q.W Overexpression of tomato tAPX gene in tobacco improves tolerance to high or low temperature stress. Biologia Plantarum, v.54, p.614-620. 2010. http:// link.springer.com/article/10.1007\%2Fs10535-010-0111-2

TORRES, M.A.; DANGL, J.L. Function of the respiratory burst oxidase in biotic interactions, abiotic stress and development. Current Opinion in Plant Biology, v.8, p.397-403, 2005. http://www.sciencedirect.com/science/article/ pii/S1369526605000750

WANG, L.; MA, H.; SONG, L.; SHU, Y.; GU, W. Comparative proteomics analysis reveals the mechanism of pre-harvest seed deterioration of soybean under high temperature and humidity stress. Journal of Proteomics, v.75, p.2109-2127. 2012. http://www.sciencedirect.com/science/article/pii/ S1874391912000243 